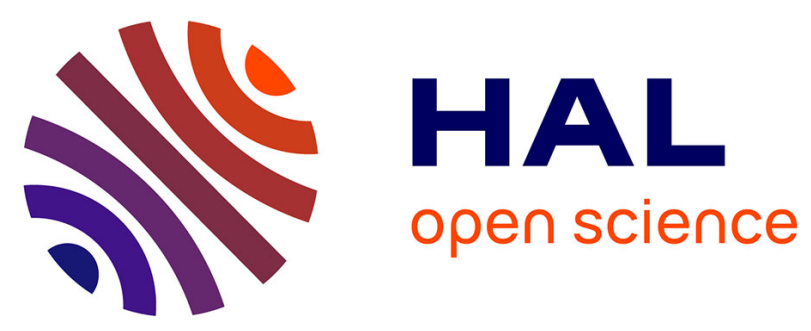

\title{
Shrink-fitting and dowel welding in mortise and tenon structural wood joints
}

Eric Mougel, Carlos Segovia, Antonio Pizzi, André Thomas

\section{To cite this version:}

Eric Mougel, Carlos Segovia, Antonio Pizzi, André Thomas. Shrink-fitting and dowel welding in mortise and tenon structural wood joints. Journal of Adhesion Science and Technology, 2011, 25 (1-3), pp.213-221. 10.1163/016942410X503320 . hal-00541133

\section{HAL Id: hal-00541133 \\ https://hal.science/hal-00541133}

Submitted on 2 Dec 2010

HAL is a multi-disciplinary open access archive for the deposit and dissemination of scientific research documents, whether they are published or not. The documents may come from teaching and research institutions in France or abroad, or from public or private research centers.
L'archive ouverte pluridisciplinaire HAL, est destinée au dépôt et à la diffusion de documents scientifiques de niveau recherche, publiés ou non, émanant des établissements d'enseignement et de recherche français ou étrangers, des laboratoires publics ou privés. 


\title{
SHRINK-FITTING AND DOWEL WELDING IN MORTISE AND TENON STRUCTURAL WOOD JOINTS
}

E.Mougel $^{1}$, C.Segovia ${ }^{1}$, A.Pizzi ${ }^{1 *}$ and A.Thomas ${ }^{2}$

${ }^{1}$ ENSTIB-LERMAB, Nancy University, 27 Rue du Merle Blanc, 88000 Epinal, France

${ }^{2}$ ENSTIB-CRAN, Nancy University, 27 Rue du Merle Blanc, 88000 Epinal, France

\begin{abstract}
Shrink-fitting, a common bonding technique in metal assemblies, was used for mortise and tenon wood joints. The joints had considerable strength. Shrink-fitting yielded joint strengths comparable to those obtained by using several welded dowels. Increasing the number of welded dowels, however, produced joints of higher strength than those bonded just by shrink-fitting. Combining in the same joint both dowel welding and shrink-fitting yielded joint strengths higher than those obtained by the individual techniques alone, and at the same time allowing decreasing the number of welded dowels needed.
\end{abstract}

Keywords: shrink-fitting, wood welding, mortise and tenon joint, dowel welding, joint strength

\section{Introduction}

Shrink-fitting is a well-known and widely used bonding technique in assemblying metallic joints. It is a method for fitting together two pieces of metal, one of which is heat-dilated and the other is shrunk by cooling it. These assemblies consist of a female and a male part, the former having a slightly smaller inner section perimeter and the latter a slightly larger outer section perimeter. The difference between these two section perimeters is called the tightening ratio. Depending on the type of shrinkfitting application, this tightening ratio can be between one tenth of a millimetre to some thousandths of a millimetre. Shrink-fitting can be applied in three distinct manners: (i) by forcing the male piece into the female one by using a press, (ii) by dilating the female piece by heating it , and (iii) by shrinking the male piece by cooling it , generally in liquid air or liquid nitrogen [1-3].

Metal shrink-fitting is done with such tight machining tolerances to generally prohibit its mounting either by hand or even by pressing. It is generally applied by using method (ii) above, up to $900^{\circ} \mathrm{C}$, or method (iii) above, or even by a combination of the two. Fitting of ball bearings and of car axles is generally done by this technique.

Shrink-fitting has been applied to wood since ancient times, for example, shrink-fitting of a heatexpanded metallic ring on the outer perimeter of a wooden cart wheel followed by water cooling has been done, to render the wooden cart wheel more durable. However, in wood, the use of shrink-fitting has almost never been industrialised. Very few and rare wood assemblies prepared using such a technique exist today. The technique is, however, well recorded in research publications and books [4-8].

Mechanically-induced friction welding techniques which are widely used in the plastic and automotive industries have recently been applied also to joining wood, without the use of any adhesive [9-13]. These techniques work by melting some wood components and forming at the interface between the

*Correspondence to: antonio.pizzi@enstib.uhp-nancy.fr 
two wood surfaces to be joined a high density composite of entangled wood fibres drowned into a matrix of molten wood intercellular material, such as lignin and hemicelluloses $[9,14]$. Rotational dowel welding, a wood welding technique, has been shown to yield joints of considerable strength [15-18].

This paper deals with the application of shrink-fitting (a) alone for its application to mortise and tenon structural joints, and (b) coupling shrink-fitting with wood dowel welding to further improve the strength of mortise and tenon structural joints.

\section{Experimental}

\subsection{Shrink-fitting}

Mortise and tenon joints in which the tenon was $20 \mathrm{~mm}$ thick, $50 \mathrm{~mm}$ wide and $300 \mathrm{~mm}$ deep (see Fig. 1) and the mortise was $20 \mathrm{~mm}$ thick, $50 \mathrm{~mm}$ wide and $50 \mathrm{~mm}$ deep (see Fig. 1) were prepared using beech wood (Fagus sylvatica). The tenons were dried to $0 \%$ moisture content in an oven at $103^{\circ} \mathrm{C}$ before being machined to the final dimensions needed for each experiment. The mortise was conditioned for three weeks in a climatic chamber at $60 \%$ relative humidity and $21^{\circ} \mathrm{C}$.

Three types of shrink fitted joints were prepared:

\section{Type 1:}

(a) Tenon before drying: $23 \mathrm{~mm}+0.02 \mathrm{~mm}$ thickness, $50 \mathrm{~mm}+0.02 \mathrm{~mm}$ width

(b) Tenon, dried: machined down to $20.4 \mathrm{~mm}+0.02 \mathrm{~mm}$ thickness, $48.5 \mathrm{~mm}+0.02 \mathrm{~mm}$ width

(c) Mortise: $20.2 \mathrm{~mm} \pm 0.05 \mathrm{~mm}$ thickness, $50 \mathrm{~mm} \pm 0.02 \mathrm{~mm}$ width

\section{Type 2}

(a) Tenon before drying : $23 \mathrm{~mm} \pm 0.02 \mathrm{~mm}$ thickness, $53 \mathrm{~mm} \pm 0.02 \mathrm{~mm}$ width

(b) Tenon, dried: machined down to $20.4 \mathrm{~mm} \pm 0.02 \mathrm{~mm}$ thickness, $49 \mathrm{~mm} \pm 0.02 \mathrm{~mm}$ width

(c) Mortise: $20.2 \mathrm{~mm} \pm 0.05 \mathrm{~mm}$ thickness, $50 \mathrm{~mm} \pm 0.02 \mathrm{~mm}$ width

\section{Type 3}

(a) Tenon before drying : $23 \mathrm{~mm}+0.02 \mathrm{~mm}$ thickness, $53 \mathrm{~mm}+0.02 \mathrm{~mm}$ width

(b) Tenon, dried: machined down to $20.4 \mathrm{~mm} \pm 0.02 \mathrm{~mm}$ thickness, $50 \mathrm{~mm} \pm 0.02 \mathrm{~mm}$ width

(c) Mortise: $20.2 \mathrm{~mm}+0.05 \mathrm{~mm}$ thickness, $50 \mathrm{~mm}+0.02 \mathrm{~mm}$ width

To determine if the wood moisture content in the different zones of the shrink-fitted joint was the determining factor in the final strength of the joint, it was measured after shrink-fitting of the joint in the three zones shown in Fig. 1.

\subsection{Dowel welding}

Mortise and tenon of the same dimensions as used in shrink fitting, i.e., tenons $20 \mathrm{~mm}$ thick, $50 \mathrm{~mm}$ wide and $300 \mathrm{~mm}$ deep (see Fig. 1) and mortises $20 \mathrm{~mm}$ thick, $50 \mathrm{~mm}$ wide and $50 \mathrm{~mm}$ deep (see Fig. 1) were assembled taking care that no shrink-fitting occurred and that the tenon was quite free to slide in and out of the mortise. The mortise and tenon were then held together by a series of beech wood fluted dowels welded through the tenon and mortise at $90^{\circ}$ to the surface of the joint. Thus, joints held together exclusively by $1,2,3,4,5,6,7$, and 8 welded dowels arranged according to the patterns shown in Fig. 2 were prepared and tested. The dowel welding conditions were: dowel length $80 \mathrm{~mm}$, dowel diameter $10 \mathrm{~mm}$, substrate hole diameter $8 \mathrm{~mm}$, rate of rotation $1750 \mathrm{rpm}$, and dowel insertion rate $18 \mathrm{~m} / \mathrm{min}$. 


\subsection{Shrink-fitting followed by dowel welding}

Mortise and tenon joints of type 3 (see Section 2.1) were shrink-fitted. The shrink-fitted joints were then dowel welded according to the same patterns and procedures described in Section 2.2.

\subsection{Strength Testing}

The shear strength of the mortise and tenon joints was tested in compression on an Instron universal testing machine by applying the force in the manner indicated in Fig.1 at a displacement rate of $2 \mathrm{~mm} / \mathrm{min}$.

\section{Results and discussion}

The results in Table 1 indicate that as shrink-fitting becomes tighter in mortise and tenon wood joints the strength of the joint increases to considerable strength. The strength results of type 3 joints are particularly noteworthy. It must be borne in mind that to extend to excess the dimensions of mortise and tennons in shrink-fitting may well lead to wood cracking with consequent loss of strength. Thus, the excellent strength results obtained in Table 1, type 3 joints, are fine when using beech wood but less extreme dimensional variation of mortise and tennon may have to be used for joints assembled from weaker softwood species.

The results of dowel welding of the same mortise and tenon joints, in which the mortise and tenon are not at all shrink-fitted, are shown in Table 2. The strength results in Table 2 are due only to the dowels welded through the joint to keep the joint together. First of all, the large dimensions of the joint have allowed the use of up to 8 welded dowels (Fig. 2). Second, the shear strength increases linearly up to 7 welded dowels and then stabilizes after this. This is the consequence of the limited area available to insert more than 7 dowels for the dimensions of the joint used. The distance between dowels and joint edges decreases and it is in the area of the substrate between the dowels, now smaller, where the joint is more prone to fail. Thus, there is a maximum number of dowels to yield maximum strength, this depends on the area of the joint in which dowels can be inserted, beyond which no benefit, or even lower results would be obtained. Third, 5 welded dowels would yield approximately the same result as the best shrink-fitted joint.

Advantages and disadvantages of the two joining methods must, however, be considered. Shrink fitting and dowel welding are both environment-friendly processes, bonding being accomplished without the use of any adhesive for both of them. However, shrink-fitting is a slow process, due to the considerable time needed to condition the wood to the wanted moisture content necessary for this technique. Dowel welding is a much faster process. A disadvantage of shrink-fitting in wood is the likely variation in joint tightness, thus in strength, the joint may undergo with variation in humidity in the environment. This would be of little consequence in interior joints, but could be rather serious under exterior conditions. From this point of view dowel welding will definitely yield a joint markedly more stable to humidity variations.

Shrink-fitting could, however, be used if coupled to dowel welding of the joint and would contribute to the strength of the joint. Table 3 shows the results obtained by coupling the two joining techniques. Thus, a joint held together by shrink-fitting of type 3 plus 4 welded dowels has strength comparable to that of a joint held together by 7 welded dowels without shrink-fitting. Interesting are, however two main trends. Firstly, combination of the two techniques improves the joint strength when 4 or more welded dowels are used. Shrink-fitting alone is capable of holding together a joint of type 3, of the dimensions under study, with a strength that is greater than that obtained with up to 4 welded dowels alone (compare Tables 1 and 2). It is interesting that the combination of the two techniques when too few dowels are used yields joint strength that is lower than that of a shrink-fitted joint alone. The only explanation for this that can be advanced is that introduction of the dowels disturbs the bondline of the shrink-fitted joint. Moreover, a joint held together by shrink-fitting of type 3 plus 5 welded dowels or 
more has strength higher than the highest strength obtained with 7 welded dowels alone or by shrinkfitting alone.

\section{Conclusion}

The metal assembly technique called shrink-fitting can be adapted to hold together mortise and tenon wood joints with a considerable strength. For certain dimensions of the joint, shrink-fitting yields joint strengths comparable to those of joints welded with welded dowels. The two joining techniques, shrink-fitting and dowel welding, can be coupled to obtain joint strengths higher than those obtained with each technique individually.

\section{Acknowledgements}

The help of X.Fenart and L.Franchi, engineering students at the ENSTIB, is gratefully acknowledged. The authors also gratefully acknowledge the financial support of the CPER 2007-2013 "Structuration du Pôle de Compétitivité Fibres Grand'Est” (Competitiveness Fibre Cluster), through local (Conseil Général des Vosges), regional (Région Lorraine), national (DRRT and FNADT) and European (FEDER) funds. 


\section{REFERENCES}

[1] D.F.Brower, US patent 3,345,732 (1967)

[2] X.Chen, R.Balendra and Y.Qin, J.Mater.Proc.Technol., 145, 215-223 (2004)

[3] Y.Lee, J.Lee, Y.Kwon and T.Ishikawa, J.Mater.Proc.Technol., 147, 102-110 (2004)

[4] C.Eckelman, E.Haviarova, A.Tankut, N.Denizli, H.Akcay and Y.Erdil, Forest Prod.J., 54, 185-191 (2004)

[5] J.Alexander, Making a Chair from a Tree. An Introduction to Working Green Wood. Taunton Press. Newtown, Connecticut (1994)

[6] R.B.Hoadley, Understanding Wood. Taunton Press. Newtown, Connecticut (1980)

[7] D.Mack, Making Rustic Furniture. Sterling Publishing Co., New York (1992)

[8] E.D.Andrews and F.Andrews, Shaker Furniture, Dover Publications, New York (1937)

[8] B.Gfeller, M.Zanetti, M.Properzi, A.Pizzi, F.Pichelin, M.Lehmann and L.Delmotte, J.Adhesion Sci.Techn., 17, 1425-1590 (2003)

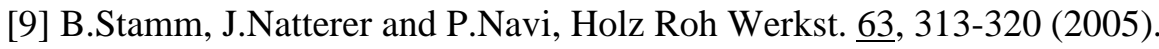

[10] L.Delmotte, H.R.Mansouri, P.Omrani and A.Pizzi, J.Adhesion Sci.Technol., 23, 1271-1279 (2009)

[11] P.Omrani, A.Pizzi, H.Mansouri, J.-M.Leban and L.Delmotte, J.Adhesion Sci.Technol., 23, 827837 (2009)

[12] H.R.Mansouri, P.Omrani and A.Pizzi, J.Adhesion Sci.Technol., 23, 63-70 (2009)

[13] C.Ganne-Chedeville, G.Duchanois, A.Pizzi, F.Pichelin, M.Properzi and J.-M.Leban, J.Adhesion Sci.Technol., 22, 169-179 (2008)

[14] J.-M.Leban, A.Pizzi, S.Wieland, M.Zanetti, M.Properzi and F.Pichelin, J.Adhesion Sci.Technol., 18, 673-685 (2004)

[15] A.Pizzi, J.-M.Leban, F.Kanazawa, M.Properzi and F.Pichelin, J.Adhesion Sci.Technol. 18, 12631278 (2004)

[16] F.Kanazawa, A.Pizzi, M.Properzi, L.Delmotte and F.Pichelin, J.Adhesion Sci.Technol. 19, 1025$1038(2005)$

[17] C.Ganne-Chedeville, A.Pizzi, A.Thomas, J.-M.Leban, J.-F.Bocquet, A.Despres and H.R.Mansouri, J.Adhesion Sci.Technol. 19, 1157-1174 (2005)

[18] A.Pizzi, A.Despres, H.R.Mansouri, J.-M.Leban and S.Rigolet, J.Adhesion Sci.Technol., 20, 427436 (2006) 
Table 1. Strength results on joints assembled by shrink-fitting only and moisture content (M.C.) in the three zones detailed in Fig. 1

\begin{tabular}{lcccc}
\hline Type of assembly & $\begin{array}{c}\text { Compression strength } \\
(\mathrm{kN})\end{array}$ & $\begin{array}{c}\text { M.C. Zone } 1 \\
(\%)\end{array}$ & $\begin{array}{c}\text { M.C. Zone } 2 \\
(\%)\end{array}$ & $\begin{array}{c}\text { M.C. Zone 3 } \\
(\%)\end{array}$ \\
\hline Type 1 & $9.4 \pm 1.03$ & $6.5 \pm 0.24$ & $7.4 \pm 0.37$ & $6.4 \pm 0.42$ \\
Type 2 & $15.4 \pm 1.34$ & $6.4 \pm 0.21$ & $8.2 \pm 0.87$ & $6.5 \pm 0.38$ \\
Type 3 & $23.6 \pm 1.37$ & $5.7 \pm 0.31$ & $7.2 \pm 0.59$ & $5.8 \pm 0.55$ \\
\hline
\end{tabular}

Table 2. Strength results on joints assembled by wood dowel welding only.

Number of Dowels Joint compression strength

$(\mathrm{kN})$

\begin{tabular}{ll}
\hline 1 & $7.1 \pm 0.97$ \\
2 & $11.6 \pm 0.77$ \\
3 & $14.6 \pm 1.39$ \\
4 & $19.5 \pm 2.41$ \\
5 & $22.5 \pm 1.76$ \\
6 & $24.9 \pm 2.59$ \\
7 & $28.1 \pm 3.71$ \\
8 & $27.7 \pm 3.70$ \\
\hline
\end{tabular}

Table 3. Joint strengths when using shrink-fitting and welded dowels together.

\begin{tabular}{lc}
\hline \multicolumn{1}{c}{ Joint type } & $\begin{array}{c}\text { Joint compression strength } \\
(\mathrm{kN})\end{array}$ \\
\hline Shrink-fitted type $3+1$ welded dowel & $7.1 \pm 0.97$ \\
Shrink-fitted type $3+2$ welded dowels & $11.6 \pm 0.7$ \\
Shrink-fitted type $3+3$ welded dowels & $14.6 \pm 1.39$ \\
Shrink-fitted type $3+4$ welded dowels & $19.5 \pm 2.41$ \\
Shrink-fitted type $3+5$ welded dowels & $22.5 \pm 1.76$ \\
\hline
\end{tabular}




\section{FIGURE LEGENDS}

Fig.1. Mortise and tenon structural joint tested for shrink-fitting and shrink-fitting plus dowel welding. The three zones presenting different moisture contents (Table 1) are indicated. (a) projection drawing and joint dimensions. (b) perspective of the joint showing the direction of the force $F$ applied on the joint specimen during the compression test.

Fig.2. Patterns of dowels insertion in zone 2 of the joint shown in Fig. 1a. a) One dowel, b) Two dowels, c) Three dowels, d) Four dowels, e) Five dowels, f) Six dowels, g) Seven dowels and h) Eight dowels. 

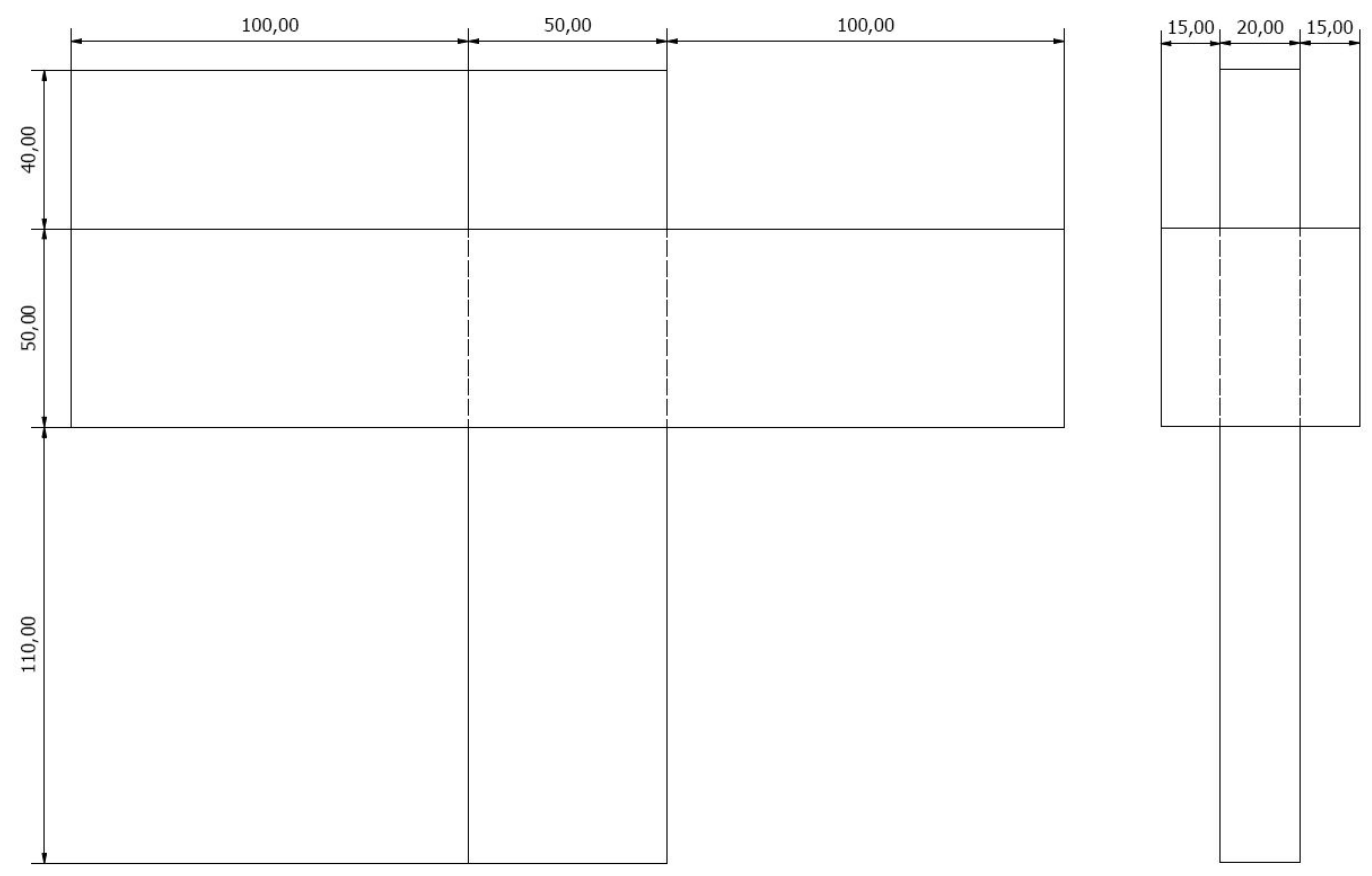

Fig. 1(a)

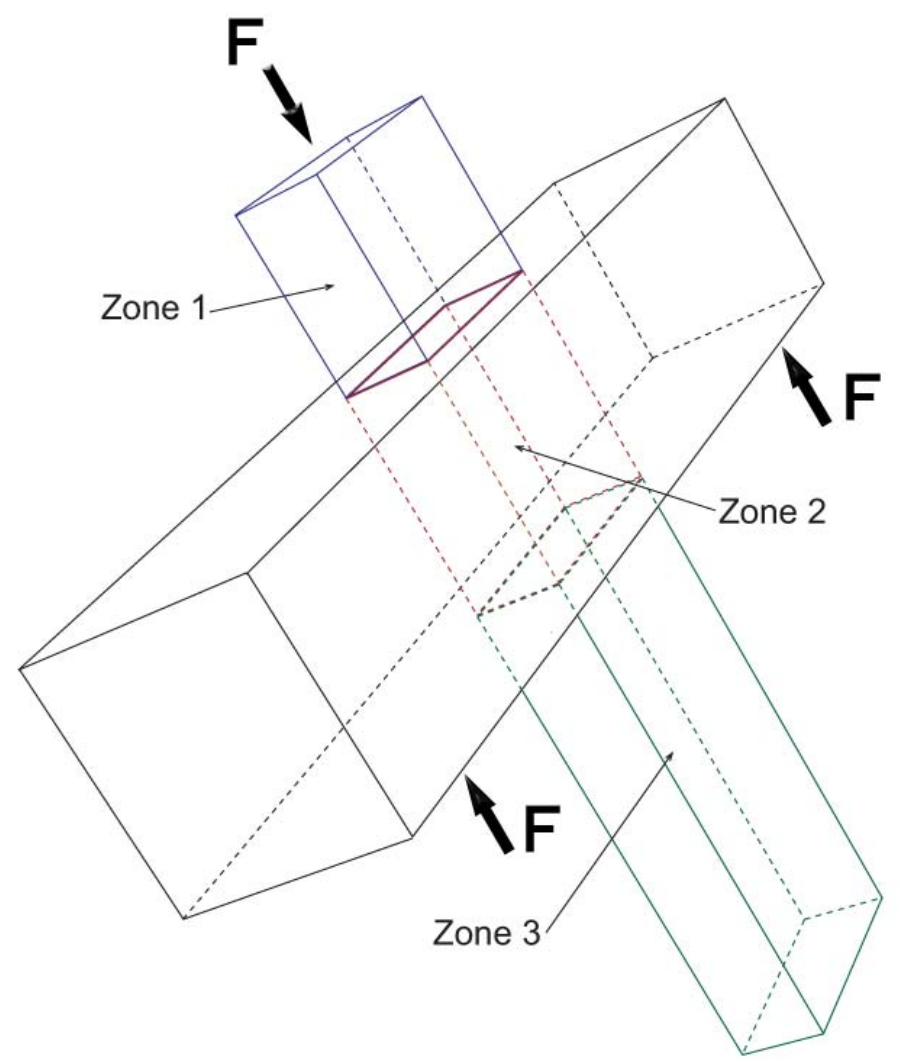

Fig. 1b

Mougel et al. 


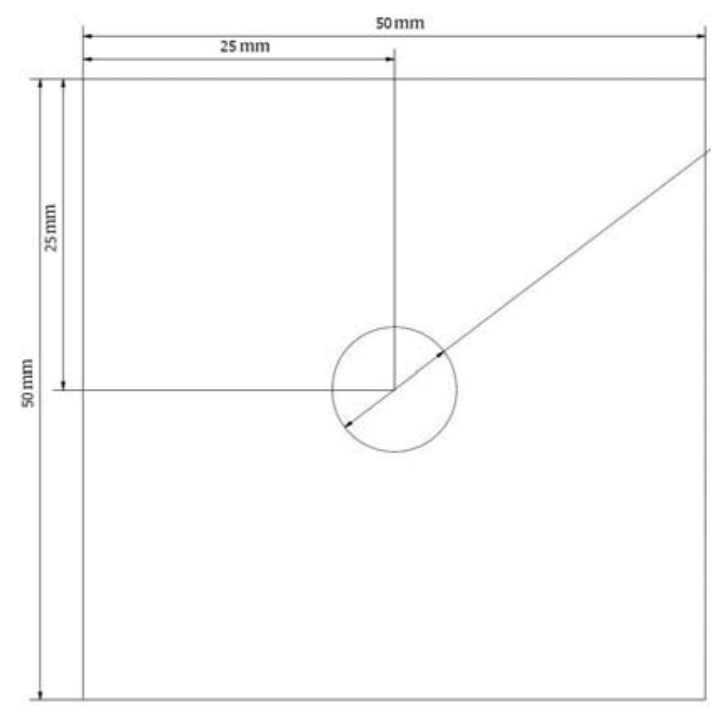

a)

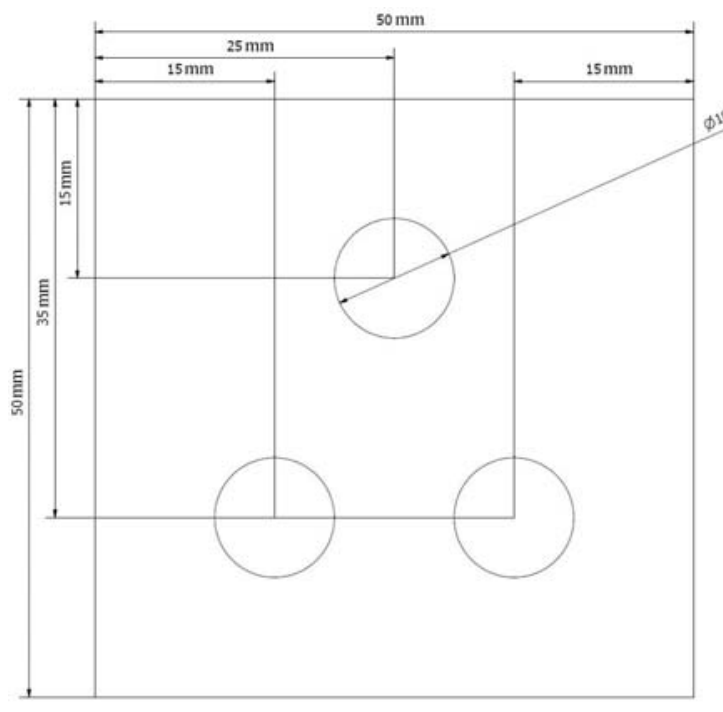

c)

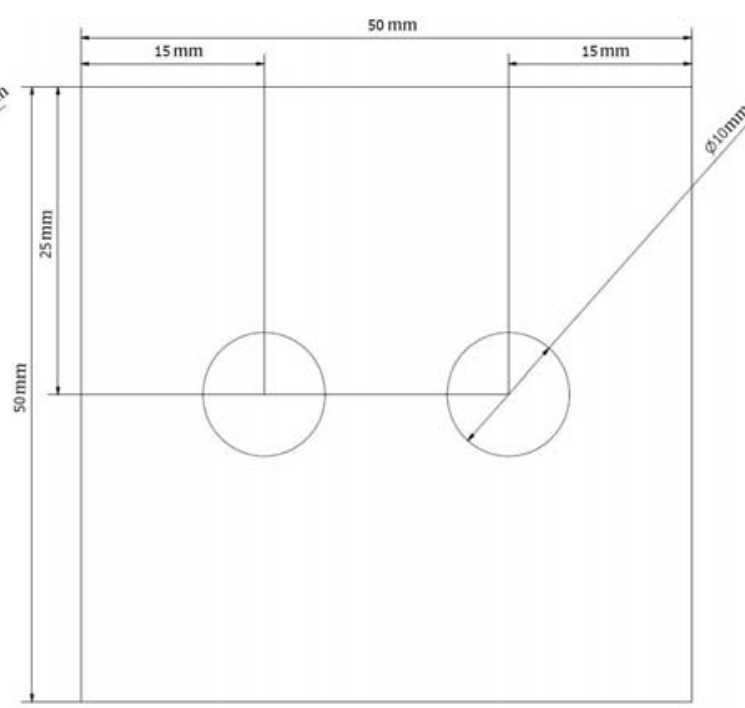

b)

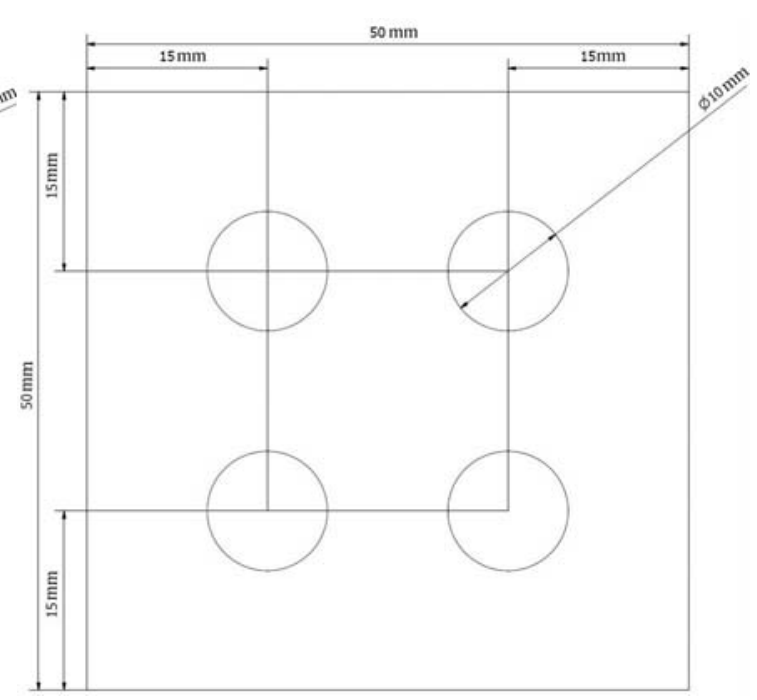

d)

Fig. 2

Mougel et al 


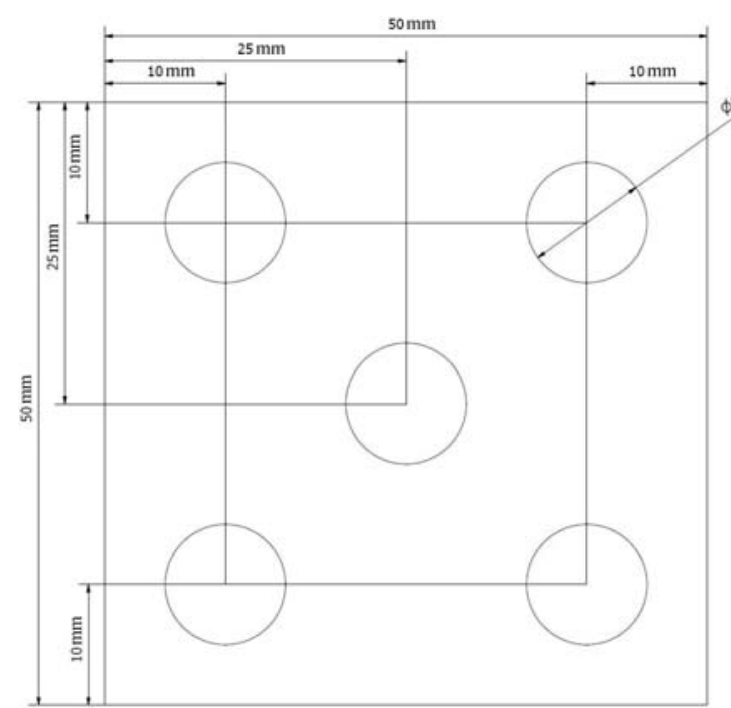

e)

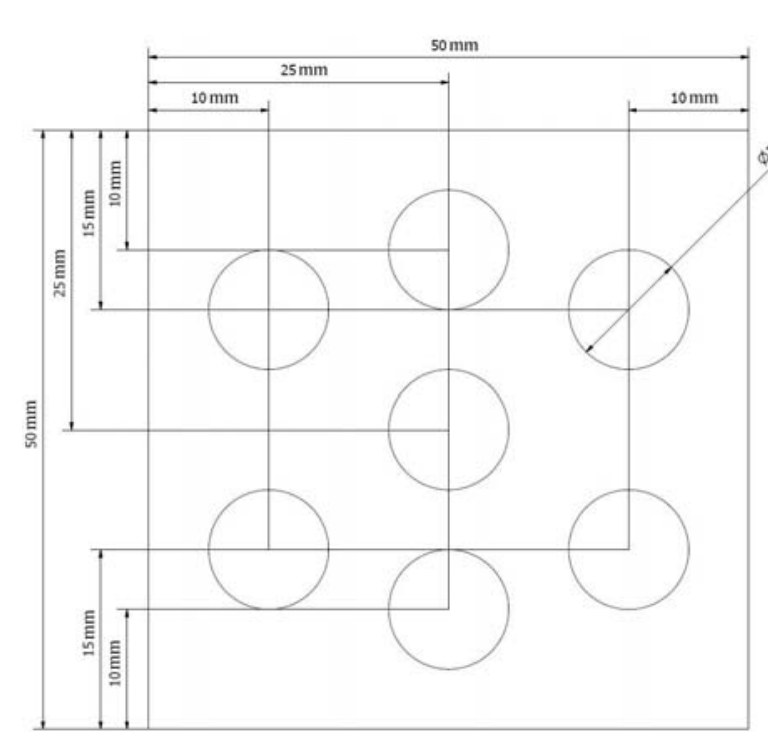

g)

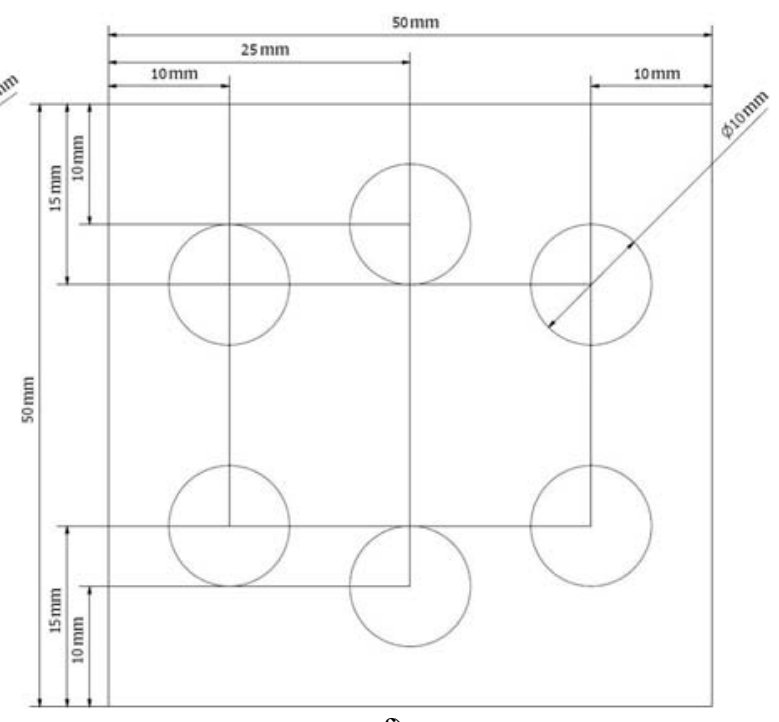

f)

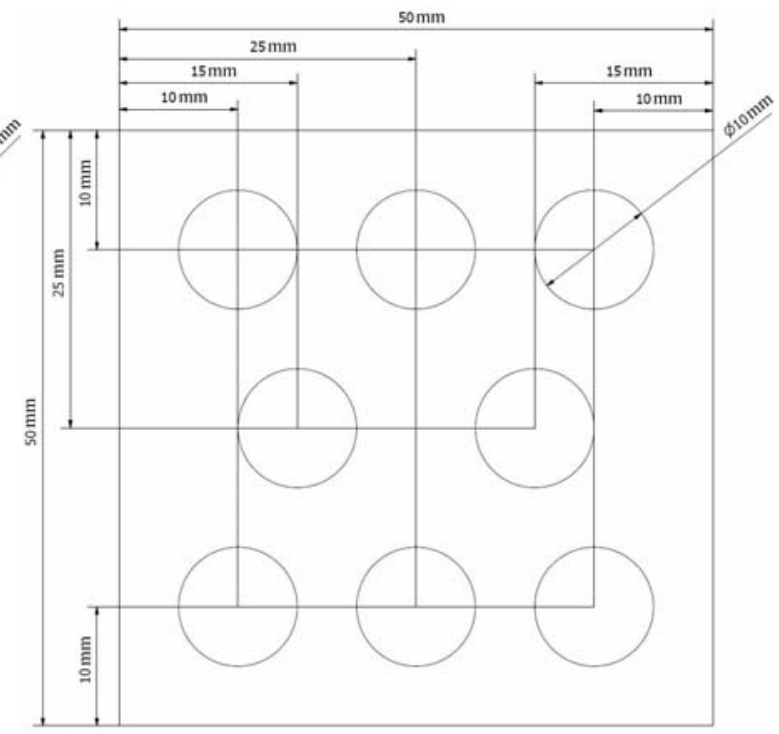

h)

Fig. 2

Mougel et al. 